\title{
Interleukin-18 serum level is elevated in type 2 diabetes and latent autoimmune diabetes
}

\author{
Emanuela Zaharieva', Zdravko Kamenov', Tsvetelina Velikova², Adelina Tsakova ${ }^{3}$, Yosif EI-Darawish ${ }^{4}$ and \\ Haruki Okamura ${ }^{4}$
}

'Department of Internal Medicine, University Hospital Alexandrovska, Clinic of Endocrinology, Faculty of Medicine, Medical University-Sofia, Sofia, Bulgaria

${ }^{2}$ Department of Clinical Immunology, University Hospital St. Ivan Rilski, Laboratory of Clinical Immunology, Faculty of Medicine, Medical University-Sofia, Sofia, Bulgaria

${ }^{3}$ Department of Clinical Laboratory, University Hospital Alexandrovska, Central Clinical Laboratory, Faculty of Medicine, Medical University-Sofia, Sofia, Bulgaria

${ }^{4}$ Laboratory of Tumor Immunology and Cell Therapy, Hyogo College of Medicine, Hyogo, Japan

Correspondence should be addressed to Z Kamenov: zkamenov@hotmail.com

\section{Abstract}

Background: Interleukin-18 (IL-18) is an inflammatory cytokine found to be elevated in Key Words obesity, metabolic syndrome and type 2 diabetes (T2D) as a part of the chronic lowgrade inflammatory process in these states. The aim of the study was to evaluate the interleukin level in patients with latent autoimmune diabetes of the adults (LADA) in

- IL-18

- LADA

type 2 diabetes comparison to that in T2D subjects.

Materials and methods: IL-18 was analyzed through enzyme-linked immunosorbent assay in 76 participants with T2D and 24 with LADA and 14 control subjects. Evaluation was also carried out in body mass index (BMI)- and glycemic control-matched diabetic patients.

Results: The serum concentration of IL-18 was higher in patients with T2D $(389.04 \pm 203.44 \mathrm{pg} / \mathrm{mL})$ and LADA $(327.04 \pm 144.48 \mathrm{pg} / \mathrm{mL})$ than that in control subjects $(219.88 \pm 91.03 \mathrm{pg} / \mathrm{mL}), P<0.05$. However, it was not significantly different between both diabetic groups $(P=0.255)$ despite higher IL-6 $(4.78 \pm 5.84$ vs $1.79 \pm 0.96 \mathrm{pg} / \mathrm{mL}, P<0.001)$ and hs-CRP $(2.60 \pm 1.70$ vs $1.29 \pm 1.20 \mathrm{mg} / \mathrm{L}, P=0.002)$ level in T2D patients. The results were persistent in BMI-matched subjects with diabetes (IL-18 $=403.48 \pm 226.32$ vs $329.30 \pm 146.30 \mathrm{pg} / \mathrm{mL}$, respectively for T2D and LADA, $P=0.391)$. The correlations in T2D group concerning HDL cholesterol $(r=-0.377, P=0.001)$, postprandial glucose $(r=0.244$, $P=0.043)$, IL-6 $(r=0.398, P<0.001)$ and hs-CRP $(r=0.427, P=0.001)$ were not confirmed in LADA and control subjects.

Conclusion: The IL-18 serum level was higher in T2D and LADA than that in control subjects, but did not differ between both diabetic groups, even when they were BMI matched. Correlations with lipid, glycemic and inflammatory parameters were present in T2D only.

\section{Introduction}

Interleukin-18 (IL-18), discovered in the late 20th century as an interferon-gamma (IFN $\gamma$ )-inducing factor (1), is a cytokine that belongs to the IL-1 superfamily (2). It is produced by monocyte/macrophages, endothelial cells, smooth muscle cells, etc. and stimulates the expression of adhesion molecules, chemokine receptors, granulocyte macrophage colony-stimulating factor (GM-CSF), IFN $\gamma$, tumor necrosis factor $\alpha(\mathrm{TNF} \alpha)$ and interleukin $1 \beta$ (IL-1 $\beta$ )

$$
\begin{array}{lr}
\text { http://www.endocrineconnections.org } & \odot 2018 \text { The authors } \\
\text { https://doi.org/10.1530/EC-17-0273 } & \text { Published by Bioscientifica Ltd }
\end{array}
$$

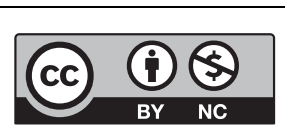

This work is licensed under a Creative Commons Attribution-NonCommercial 4.0 International License. 
and activates type 1 or type $2 \mathrm{~T}$ helper immune response $(3,4)$. Apart from its place in immune defense against infective pathogens, IL-18 participates in the pathogenesis of atopic, autoimmune and chronic inflammatory diseases $(3,4)$.

Obesity and type 2 diabetes (T2D) have been associated with a chronic low-grade inflammation (5) that has been implicated as a crucial factor for insulin resistance (6) and also beta-cell dysfunction $(7,8)$. Patients diagnosed with latent autoimmune diabetes of the adults (LADA) (9), considered by many an indistinguishable part of type 1 diabetes (T1D) $(10,11,60)$, usually present with a better metabolic profile and inflammatory markers than T2D, even though optimal glycemic control is usually harder to achieve (12).

Like other pro-inflammatory cytokines (such as IL-1 $\beta$, TNF $\alpha$, interleukin 6 (IL-6) $(13,14,15,16)$ and highsensitivity C-reactive protein (hs-CRP) (17)), elevated IL-18 level is a characteristic of obesity and the metabolic syndrome $(18,19,20)$, and is reduced by weight loss $(19$, $21)$. The presence of the metabolic syndrome is associated with even higher IL-18 concentration than obesity alone, as has been shown for IL-6, TNF $\alpha$ and CRP (22). It is now well known that adipose tissue is a major contributor to inflammatory cytokine release in these states (23). As with other adipokines $(24,25)$, adipocytes can produce IL-18 $(26,27)$, but they do not seem to be the main source of the interleukin - rather it is being predominantly released by infiltrating macrophages (28).

Elevated IL-18 plasma level has been observed in vivo in response to acute hyperglycemia in healthy volunteers and subjects with impaired glucose tolerance (29). Patients with newly diagnosed T2D have been shown to have a significantly higher IL-18 level in comparison to nondiabetic subjects $(30,31)$. This elevation correlates with various factors used in the assessment of the metabolic risk - BMI, waist circumference, HDL cholesterol, triglycerides, blood pressure control, basal insulin, fasting plasma glucose $(31,32,33)$ and insulin resistance index (34). Changes in IL-18 seem to be predictive of the risk of prediabetes $(35)$ and $\mathrm{T} 2 \mathrm{D}(35,36,37)$ in a way that is independent of other markers that reflect the ongoing chronic subclinical inflammation (37). They also contribute to determining the cardiovascular risk in the presence of a metabolic syndrome (38).

The aim of the current study was to compare the serum level of IL-18 between patients with T2D and subjects who meet the criteria for LADA (39) and to estimate its association with weight, glycemic and lipid control, as well as that of the inflammatory markers IL-6 and hs-CRP within both groups.

\section{Subjects and methods}

One hundred patients with diabetes were enrolled in this study - 76 patients with T2D and 24 with LADA and 14 control participants. The protocol of the study was in accordance with the declaration of Helsinki (40) and was approved by the ethics committee of Medical UniversitySofia. All participants have signed an informed consent. Patients with LADA were enrolled if medical history included all of the following criteria: (1) onset at the age of 35 years or over; (2) presence of positive diabetesassociated autoantibodies, such as islet-cell cytoplasm autoantibodies (ICA), glutamic acid decarboxylase autoantibodies (GAD65A) (41), insulinoma-associated-2 antibodies - tyrosine phosphatase-associated (IA-2A) (42), zinc transporter 8 autoantibodies (ZnT8A) (43); (3) no need for insulin treatment for at least 6 months after diagnosis (39). All participants were assayed for GAD65A within the study as well (Supplementary Table 1, see section on supplementary data given at the end of this article).

The control groups consisted of healthy volunteers with a BMI $<30 \mathrm{~kg} / \mathrm{m}^{2}$. Presence of the metabolic syndrome was assessed through the International Diabetes Federation criteria (44).

Blood samples were obtained after an overnight fasting state. Lipid profile, fasting plasma glucose (FPG) and 2-h post standard lunch meal postprandial plasma glucose (PPG), HbA1c were assessed by standard techniques in the Central Laboratory of the University hospital, which is the referent hospital for Bulgaria. IL-6 was analyzed by electro-chemiluminescence immunoassay on Roche Elecsys 2010 (Roche Diagnostics $\mathrm{GmbH}$ ) and hs-CRP by particle enhanced immunoturbidimetric assay on Cobas Integra 400 Plus (Roche Diagnostics $\mathrm{GmbH}$ ) with a lower detection limit of $1.5 \mathrm{pg} / \mathrm{mL}$ and $0.15 \mathrm{mg} / \mathrm{L}$, respectively. IL-18 was analyzed by enzyme-linked immunosorbent assay (ELISA) (Medical \& Biological Laboratories Co., Ltd, Nagoya, Japan) with a detection limit of $12.5 \mathrm{pg} / \mathrm{mL}$. GAD65A were assayed by ELISA (Euroimmune Medizinische Labordiagnostika AG, Lübeck, Germany) with a diagnostic cut-off at $10 \mathrm{IU} / \mathrm{mL}$ and a sensitivity and specificity, evaluated in the 2005 Diabetes Autoantibody Standardization Program workshop, of $92 \%$ and $98 \%$, respectively.

$$
\text { http://www.endocrineconnections.org }
$$
https://doi.org/10.1530/EC-17-0273
() 2018 The authors Published by Bioscientifica Ltd
This work is licensed under a Creative Commons Attribution-NonCommercial 4.0 International License. 


\section{Statistical analysis}

Statistical analysis was performed with SPSS 21 statistics package. Comparison of data between independent samples was analyzed through the Mann-Whitney $U$ test. Spearman's rank correlation coefficient was computed for correlations. Fisher's exact test was used for assessing differences in frequencies between groups. $P$ values less than 0.05 were considered significant.

\section{Results}

Subjects' characteristics are detailed in Table 1. Patients from both diabetic groups had a significantly higher serum level of IL-18 than the control participants. Taking into consideration the significant difference in gender distribution between T2D subjects and control participants, re-evaluation of the serum level only in women from these groups confirmed a significantly higher serum concentration of the IL-18 in T2D $(n=43)$ than in control $(n=13)$ participants $(400 \pm 197$ vs $222 \pm 94 \mathrm{pg} / \mathrm{mL}$, $P<0.001)$

Despite the subjects with T2D and LADA having significantly different anthropometric parameters and glycemic control, and the T2D group having a higher IL-6 and hs-CRP level, the IL-18 level was not significantly different between both diabetic groups. Analysis between BMI-matched diabetic patients, who still differed in some parameters used in the assessment of metabolic risk (44) but had similar glycemic control, showed that the IL-6 and hs-CRP, although not significantly for the latter, remained higher in T2D group. The difference in the level of IL-18 was still not significant between both diabetic groups (Table 1).

Comparison in IL-18 level between BMI-matched T2D $(n=8)$ and control $(n=13)$ participants $(\mathrm{BMI}=22.51 \pm 1.08$ vs $21.47 \pm 1.73 \mathrm{~kg} / \mathrm{m}^{2}, P=0.147 ; \mathrm{WC}=82 \pm 8$ vs $78 \pm 8 \mathrm{~cm}$, $P=0.50)$ demonstrated a persistent higher level of the cytokine in the diabetic than that in control subjects (IL$18=430 \pm 224$ vs $218 \pm 94 \mathrm{pg} / \mathrm{mL}, P=0.007)$.

This was also observed (IL-18 $=326 \pm 135$ vs $220 \pm 91 \mathrm{pg} / \mathrm{mL}, \quad P=0.027)$ between the LADA cohort $(n=14)$ and control participants $(n=14)$ when anthropometric parameters were not significantly different $\quad\left(B M I=22.63 \pm 2.40 \quad\right.$ vs $21.72 \pm 1.91 \mathrm{~kg} / \mathrm{m}^{2}$, $P=0.214, \mathrm{WC}=83 \pm 8$ vs $77 \pm 8 \mathrm{~cm}, P=0.054)$.

The correlation analysis showed significant findings in the T2D group concerning relationship between the IL-18 level and glycemic and lipid control, but not

$\begin{array}{lr}\text { http://www.endocrineconnections.org } & \text { ○ } 2018 \text { The authors } \\ \text { https://doi.org/10.1530/EC-17-0273 } & \text { Published by Bioscientifica Ltd }\end{array}$

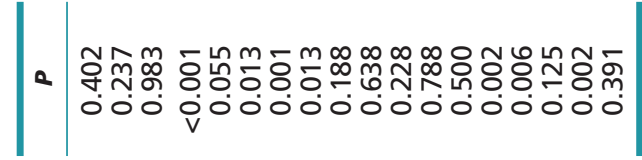
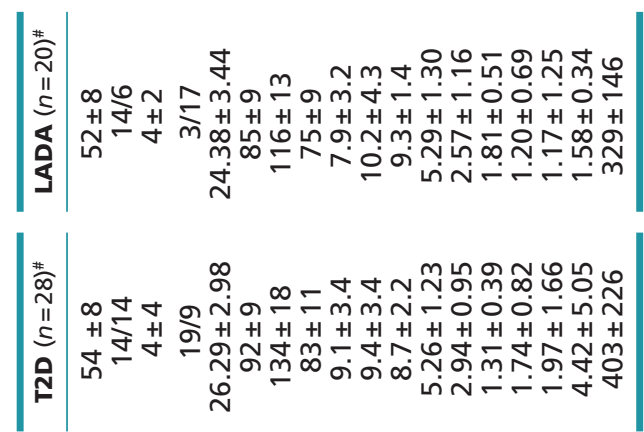

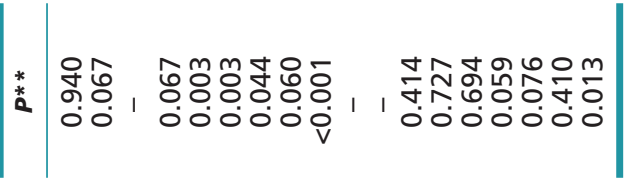

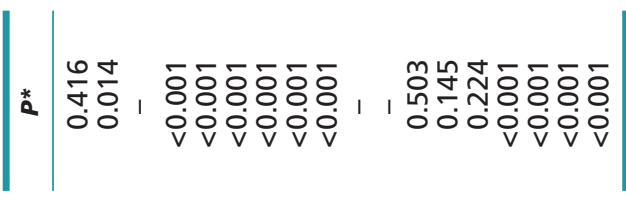
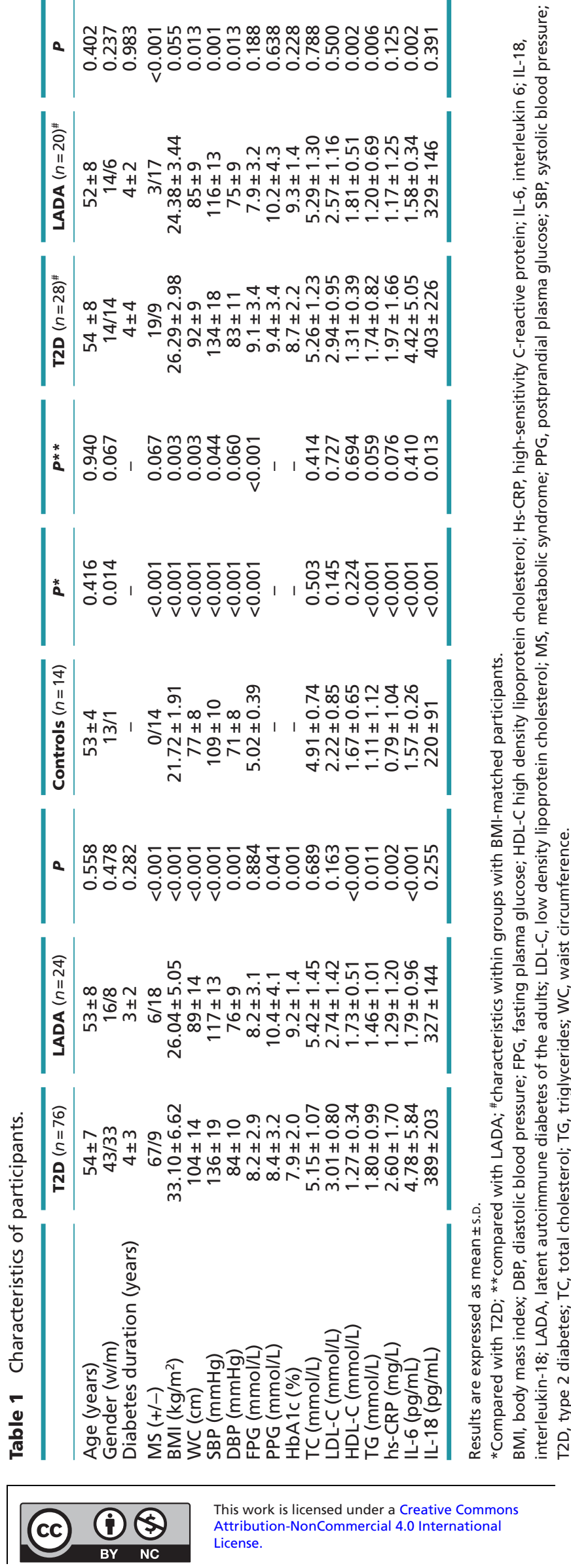

This work is licensed under a Creative Commons Attribution-NonCommercial 4.0 International License. 
Table 2 Correlation coefficients between IL-18 and clinical, metabolic and inflammatory parameters.

\begin{tabular}{|c|c|c|c|c|}
\hline & \multicolumn{2}{|c|}{ T2D $(n=76)$} & \multicolumn{2}{|c|}{ LADA $(n=24)$} \\
\hline & $r$ & $P$ & $r$ & $P$ \\
\hline BMI $\left(\mathrm{kg} / \mathrm{m}^{2}\right)$ & 0.015 & 0.897 & 0.210 & 0.325 \\
\hline WC (cm) & 0.073 & 0.532 & 0.297 & 0.169 \\
\hline SBP $(\mathrm{mmHg})$ & -0.037 & 0.749 & 0.289 & 0.171 \\
\hline $\mathrm{DBP}(\mathrm{mmHg})$ & -0.094 & 0.418 & 0.133 & 0.535 \\
\hline FPG (mmol/L) & 0.075 & 0.530 & -0.098 & 0.655 \\
\hline PPG (mmol/L) & 0.244 & 0.043 & 0.027 & 0.907 \\
\hline HbA1c (\%) & 0.007 & 0.956 & 0.168 & 0.434 \\
\hline LDL-C (mmol/L) & -0.141 & 0.251 & 0.134 & 0.563 \\
\hline $\mathrm{HDL}-\mathrm{C}(\mathrm{mmol} / \mathrm{L})$ & -0.377 & 0.001 & -0.392 & 0.079 \\
\hline TG (mmol/L) & 0.072 & 0.546 & 0.301 & 0.154 \\
\hline hs-CRP (mg/L) & 0.427 & 0.001 & 0.113 & 0.832 \\
\hline IL-6 (pg/mL) & 0.398 & $<0.001$ & -0.131 & 0.541 \\
\hline
\end{tabular}

\begin{tabular}{|c|c|}
\hline \multicolumn{2}{|c|}{ Controls $(n=14)$} \\
\hline$r$ & $P$ \\
\hline 0.004 & 0.988 \\
\hline 0.064 & 0.827 \\
\hline 0.527 & 0.053 \\
\hline 0.507 & 0.064 \\
\hline 0.483 & 0.094 \\
\hline- & - \\
\hline- & - \\
\hline-0.500 & 0.667 \\
\hline 0.500 & 0.667 \\
\hline-0.172 & 0.557 \\
\hline-0.241 & 0.406 \\
\hline-0.241 & 0.406 \\
\hline
\end{tabular}

\begin{tabular}{|c|c|}
\hline \multicolumn{2}{|c|}{ T2D $(n=28)^{\#}$} \\
\hline$r$ & $P$ \\
\hline 0.240 & 0.219 \\
\hline 0.219 & 0.262 \\
\hline 0.172 & 0.382 \\
\hline 0.080 & 0.687 \\
\hline 0.152 & 0.449 \\
\hline 0.290 & 0.151 \\
\hline 0.059 & 0.771 \\
\hline-0.099 & 0.645 \\
\hline-0.464 & 0.019 \\
\hline 0.044 & 0.829 \\
\hline 0.493 & 0.017 \\
\hline 0.408 & 0.035 \\
\hline
\end{tabular}

\begin{tabular}{|c|c|}
\hline \multicolumn{2}{|c|}{ LADA $(n=20)^{\#}$} \\
\hline$r$ & $P$ \\
\hline 0.328 & 0.158 \\
\hline 0.379 & 0.110 \\
\hline 0.228 & 0.333 \\
\hline 0.067 & 0.780 \\
\hline-0.261 & 0.280 \\
\hline-0.001 & 0.997 \\
\hline 0.157 & 0.508 \\
\hline 0.059 & 0.823 \\
\hline-0.412 & 0.101 \\
\hline 0.281 & 0.231 \\
\hline 0.128 & 0.591 \\
\hline 0.020 & 0.934 \\
\hline
\end{tabular}

\#Correlations within groups with BMI-matched participants.

BMI, body mass index; DBP, diastolic blood pressure; FPG, fasting plasma glucose; HDL-C, high density lipoprotein cholesterol; Hs-CRP, high-sensitivity C-reactive protein; IL-6, interleukin 6; IL-18, interleukin-18; LADA, latent autoimmune diabetes of the adults; LDL-C, low density lipoprotein cholesterol; PPG, postprandial plasma glucose; SBP, systolic blood pressure; T2D, type 2 diabetes; TG, triglycerides; WC, waist circumference.

obesity, assessed by both BMI and waist circumference. However, IL-18 correlated positively with both IL-6 and hs-CRP serum concentrations only in T2D group. Results concerning IL-6, hs-CRP and HDL cholesterol were similar even when analysis included subjects with lower BMI. None of these results was observed in the LADA and control groups (Table 2).

\section{Discussion}

Chroniclow-grade inflammation is part of the pathogenesis of T2D (5), while LADA seems to be characterized with lower levels of inflammatory cytokines like IL-6 and TNF $\alpha$ (45). Serine phosphorylation of insulin receptor substrate (IRS), inhibition of the tyrosine kinase activity of the insulin receptor, ubiquitination and degradation of both IRS1 and IRS2, decreased transcription of IRS1 mRNA are some of the mechanisms involved in the reduction of insulin sensitivity in hepatocytes, adipocytes and muscles by the increased level of inflammatory cytokines (46). Whether IL-18 contributes to insulin resistance (47) is still not well understood although it has been associated with signal transducer and activator of transcription (STAT) signaling (48). Although insulin resistance cannot be excluded in some cases of autoimmune diabetes $(49,50)$, the metabolic syndrome and associated chronic inflammation are less often observed than in T2D $(12,45)$.

Unchanged serum concentration of IL-18 in LADA in comparison to T2D could be attributed to the stimulatory effect of hyperglycemia (51), and also to the involvement of the cytokine in autoimmune diseases, including diabetes mellitus (52). Increased level of IL-18 has been observed in some autoimmune diseases as multiple sclerosis, myasthenia gravis, systemic lupus erythematosus, Sjögren syndrome and rheumatoid arthritis, in both experimental models and clinical practice (52). It has been found to be elevated in T1D as well and its higher expression in the islets could be involved in the autoimmune response against beta-cells $(51,53)$. We have not been able to find data about the serum concentration of IL-18 in LADA in the literature, but being considered a part of the spectrum of T1D $(10,11,60)$, we cannot exclude that its level in circulation is influenced by autoimmune processes in the islets.

It has been previously shown that IL- 6 and TNF $\alpha$ levels differ significantly in subjects with T2D and patients with late-onset diabetes and positive antiGAD65 autoantibodies (45) and we have also confirmed different inflammatory parameters in both states (54). Despite the expected higher serum concentrations of IL-6 and hs-CRP in T2D patients when compared with LADA, the level of another potent pro-inflammatory cytokine, namely IL-18, remained unchanged between participants from both groups. The current positive correlation between IL-18 and IL-6, together with hs-CRP, is in line with a previously observed association between them and the metabolic syndrome (22). The latter was much more prevalent in T2D even in BMI-matched participants in the current study. Although correlations of IL-18 with HbA1c, PPG and HDL cholesterol have been previously described in T1D (55), here they were not confirmed in subjects with LADA. One reason for the lack of association between lipid, glycemic and
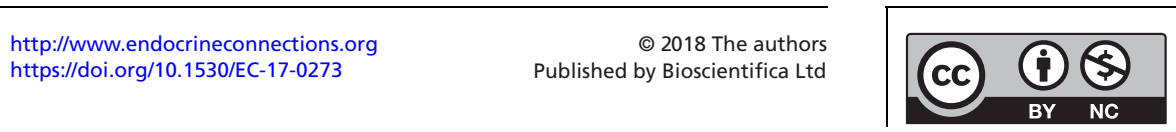


\section{IL-1}

inflammatory parameters in these participants could be the lower prevalence of the metabolic syndrome, as the association of IL-18 with the latter seems to be stronger than that with obesity (22).

Another possible explanation concerns a dominant role of IL-18 in the autoimmune pathogenesis of LADA and not the insulin resistance-associated chronic lowgrade inflammation in this type of diabetes mellitus. Although beta-cell dysfunction in T2D has recently also been associated with insulitis (56), it is currently not clear whether IL-18 contributes to beta-cell apoptosis in T2D as has been demonstrated for other cytokines (57).

Lack of association between IL-18 and the described metabolic and inflammatory parameters could even result from both the metabolic and immunologic factors discussed. It has been shown that LADA could present with a heterogeneous clinical and immunologic characteristics moving it closer to either T1D or T2D (58). A larger cohort of participants with LADA with both phenotypes and related GAD65A titer (59) would clarify the role of IL-18 in metabolic control-associated low-grade chronic inflammation and autoimmune process.

The main limitations of the study are the relatively low number of participants, a higher percentage of the female gender in all groups and the significant difference in the prevalence of the metabolic syndrome between groups, even when they were BMI matched. However, we have not been able to find another study that compares the IL-18 serum level between T2D and LADA, and these results add to current knowledge of the cytokine's place in diabetes mellitus and prompts further investigations of the subject.

\section{Conclusion}

The current study showed a higher serum level of IL-18 in patients with T2D and LADA than in the control subjects, but a similar one between both diabetic groups even after matching them for BMI and glycemic control. Correlations with glycemic, lipid and inflammatory parameters were observed in T2D only. Further analysis is needed to distinguish the role of IL-18 in insulinresistance-associated chronic low-grade inflammation from that in the autoimmune response in LADA.

\section{Supplementary data}

This is linked to the online version of the paper at https://doi.org/10.1530/ EC-17-0273.

\footnotetext{
http://www.endocrineconnections.org
https://doi.org/10.1530/EC-17-0273
}

(c) 2018 The authors Published by Bioscientifica Ltd

\section{Declaration of interest}

The authors declare that there is no conflict of interest that could be perceived as prejudicing the impartiality of the research reported.

\section{Funding}

The study was financially supported by Medical University-Sofia with grant number 6-D/2014.

\section{Acknowledgements}

IL-18 ELISA kits were provided by Hirakata Ryōikuen Osaka.

\section{References}

1 Okamura H, Tsutsi H, Komatsu T, Yutsudo M, Hakura A, Tanimoto T, Torigoe K, Okura T, Nukada Y, Hattori K, et al. Cloning of a new cytokine that induces IFN-gamma production by T cells. Nature 1995 378 88-91. (https://doi.org/10.1038/378088a0)

2 Dinarello CA. Interleukin-18, a proinflammatory cytokine. European Cytokine Network 200011 483-486.

3 Dinarello CA. The IL-1 family and inflammatory diseases. Clinical and Experimental Rheumatology 200220 S1-S13.

4 Nakanishi K, Yoshimoto T, Tsutsui H \& Okamura H. Interleukin-18 is a unique cytokine that stimulates both Th1 and Th2 responses depending on its cytokine milieu. Cytokine and Growth Factor Reviews 200112 53-72. (https://doi.org/10.1016/S1359-6101(00)00015-0)

5 Hameed I, Masoodi SR, Mir SA, Nabi M, Ghazanfar K \& Ganai BA. Type 2 diabetes mellitus: from a metabolic disorder to an inflammatory condition. World Journal of Diabetes 20156 598-612. (https://doi.org/10.4239/wjd.v6.i4.598)

6 Ye J. Mechanisms of insulin resistance in obesity. Frontiers of Medicine 20137 14-24. (https://doi.org/10.1007/s11684-013-0262-6)

7 Ehses JA, Perren A, Eppler E, Ribaux P, Pospisilik JA, Maor-Cahn R, Gueripel X, Ellingsgaard H, Schneider MK, Biollaz G, et al. Increased number of islet-associated macrophages in type 2 diabetes. Diabetes 200756 2356-2370. (https://doi.org/10.2337/db06-1650)

8 Eguchi K, Manabe I, Oishi-Tanaka Y, Ohsugi M, Kono N, Ogata F, Yagi N, Ohto U, Kimoto M, Miyake K, et al. Saturated fatty acid and TLR signaling link $\beta$ cell dysfunction and islet inflammation. Cell Metabolism 201215 518-533. (https://doi.org/10.1016/j. cmet.2012.01.023)

9 Zimmet PZ, Tuomi T, Mackay IR, Rowley MJ, Knowles W, Cohen M $\&$ Lang DA. Latent autoimmune diabetes mellitus in adults (LADA): the role of antibodies to glutamic acid decarboxylase in diagnosis and prediction of insulin dependency. Diabetes Medicine 199411 299-303. (https://doi.org/10.1111/j.1464-5491.1994.tb00275.x)

10 Redondo MJ. LADA: time for a new definition. Diabetes 201362 339-340. (https://doi.org/10.2337/db12-1171)

11 Gale EA. Latent autoimmune diabetes in adults: a guide for the perplexed. Diabetologia 200548 2195-2199. (https://doi.org/10.1007/ s00125-005-1954-5)

12 Hawa MI, Thivolet C, Mauricio D, Alemanno I, Cipponeri E, Collier D, Hunter S, Buzzetti R, de Leiva A, Pozzilli P, et al. Metabolic syndrome and autoimmune diabetes: action LADA 3. Diabetes Care 200932 160-164. (https://doi.org/10.2337/dc08-1419)

13 Moschen AR, Molnar C, Enrich B, Geiger S, Ebenbichler CF \& Tilg H. Adipose and liver expression of interleukin (IL)-1 family members in morbid obesity and effects of weight loss. Molecular Medicine 201117 840-845. (https://doi.org/10.2119/molmed.2010.00108)

14 Kern PA, Saghizadeh M, Ong JM, Bosch RJ, Deem R \& Simsolo RB. The expression of tumor necrosis factor in human adipose tissue. Regulation by obesity, weight loss, and relationship to lipoprotein 
lipase. Journal of Clinical Investigation 199595 2111-2119. (https://doi.org/10.1172/JCI117899)

15 Bastard JP, Jardel C, Bruckert E, Blondy P, Capeau J, Laville M, Vidal H \& Hainque B. Elevated levels of interleukin 6 are reduced in serum and subcutaneous adipose tissue of obese women after weight loss. Journal of Clinical Endocrinology and Metabolism 200085 3338-3342. (https://doi.org/10.1210/jcem.85.9.6839)

16 Jung SH, Park HS, Kim KS, Choi WH, Ahn CW, Kim BT, Kim SM, Lee SY, Ahn SM, Kim YK, et al. Effect of weight loss on some serum cytokines in human obesity: increase in IL-10 after weight loss. Journal of Nutritional Biochemistry 200819 371-375. (https://doi. org/10.1016/j.jnutbio.2007.05.007)

17 Tchernof A, Nolan A, Sites CK, Ades PA \& Poehlman ET. Weight loss reduces C-reactive protein levels in obese postmenopausal women. Circulation 2002105 564-569. (https://doi.org/10.1161/ hc0502.103331)

18 Escobar-Morreale HF, Botella-Carretero JI, Villuendas G, Sancho J \& San Millán JL. Serum interleukin-18 concentrations are increased in the polycystic ovary syndrome: relationship to insulin resistance and to obesity. Journal of Clinical Endocrinology and Metabolism 200489 806-811. (https://doi.org/10.1210/jc.2003-031365)

19 Esposito K, Pontillo A, Ciotola M, Di Palo C, Grella E, Nicoletti G \& Giugliano D. Weight loss reduces interleukin-18 levels in obese women. Journal of Clinical Endocrinology and Metabolism 200287 3864-3866. (https://doi.org/10.1210/jcem.87.8.8781)

20 Angelova P, Kamenov Z, Tsakova A, El-Darawish Y \& Okamura H. Interleukin-18 and testosterone levels in men with metabolic syndrome. Aging Male [epub]. (https://doi.org/10.1080/13685538.201 7.1401993)

21 Tajik N, Keshavarz SA, Masoudkabir F, Djalali M, SadrzadehYeganeh HH, Eshraghian MR, Chamary M, Ahmadivand Z, Yazdani T \& Javanbakht MH. Effect of diet-induced weight loss on inflammatory cytokines in obese women. Journal of Endocrinological Investigation 201336 211-215. (https://doi.org/10.3275/8465)

22 Van Guilder GP, Hoetzer GL, Greiner JJ, Stauffer BL \& Desouza CA. Influence of metabolic syndrome on biomarkers of oxidative stress and inflammation in obese adults. Obesity 200614 2127-2131. (https://doi.org/10.1038/oby.2006.248)

23 Gregor MF \& Hotamisligil GS. Inflammatory mechanisms in obesity. Annual Review of Immunology 201129 415-445. (https://doi. org/10.1146/annurev-immunol-031210-101322)

24 Weisberg SP, McCann D, Desai M, Rosenbaum M, Leibel RL \& Ferrante AW Jr. Obesity is associated with macrophage accumulation in adipose tissue. Journal of Clinical Investigation $2003 \mathbf{1 1 2}$ 1796-1808. (https://doi.org/10.1172/JCI19246)

$25 \mathrm{Xu} \mathrm{H}$, Barnes GT, Yang Q, Tan G, Yang D, Chou CJ, Sole J, Nichols A, Ross JS, Tartaglia LA, et al. Chronic inflammation in fat plays a crucial role in the development of obesity-related insulin resistance. Journal of Clinical Investigation 2003112 1821-1830. (https://doi. org/10.1172/JCI19451)

26 Skurk T, Kolb H, Muller-Scholze S, Rohrig K, Hauner H \& Herder C. The proatherogenic cytokine interleukin-18 is secreted by human adipocytes. European Journal of Endocrinology 2005152 863-868. (https://doi.org/10.1530/eje.1.01897)

27 Wood IS, Wang B, Jenkins JR \& Trayhurn P. The pro-inflammatory cytokine IL-18 is expressed in human adipose tissue and strongly upregulated by TNFalpha in human adipocytes. Biochemical and Biophysical Research Communications 2005337 422-429. (https://doi. org/10.1016/j.bbrc.2005.09.068)

28 Fain JN, Tichansky DS \& Madan AK. Most of the interleukin 1 receptor antagonist, cathepsin $\mathrm{S}$, macrophage migration inhibitory factor, nerve growth factor, and interleukin 18 release by explants of human adipose tissue is by the non-fat cells, not by the adipocytes. Metabolism 200655 1113-1121. (https://doi.org/10.1016/j. metabol.2006.04.008)
29 Esposito K, Nappo F, Marfella R, Giugliano G, Giugliano F, Ciotola M, Quagliaro L, Ceriello A \& Giugliano D. Inflammatory cytokine concentrations are acutely increased by hyperglycemia in humans: role of oxidative stress. Circulation 2002106 2067-2072. (https://doi. org/10.1161/01.CIR.0000034509.14906.AE)

30 Esposito K, Nappo F, Giugliano F, Di Palo C, Ciotola M, Barbieri M, Paolisso G \& Giugliano D. Cytokine milieu tends toward inflammation in type 2 diabetes. Diabetes Care 2003261647. (https://doi.org/10.2337/diacare.26.5.1647)

31 Aso Y, Okumura K, Takebayashi K, Wakabayashi S \& Inukai T. Relationships of plasma IL-18 concentrations to hyperhomocysteinemia and carotid intimal-media wall thickness in patients with type 2 diabetes. Diabetes Care 200326 2622-2627. (https://doi.org/10.2337/diacare.26.9.2622)

32 Hung J, McQuillan BM, Chapman CM, Thompson PL \& Beilby JP. Elevated interleukin-18 levels are associated with the metabolic syndrome independent of obesity and insulin resistance. Arteriosclerosis, Thrombosis, and Vascular Biology 200525 1268-1273. (https://doi.org/10.1161/01.ATV.0000163843.70369.12)

33 Evans J, Collins M, Jennings C, van der Merwe L, Soderstrom I \& Olsson T. The association of interleukin-18 genotype and serum levels with metabolic risk factors for cardiovascular disease. European Journal of Endocrinology 2007157 633-640. (https://doi.org/10.1530/ EJE-07-0463)

34 Fischer CP, Perstrup LB, Berntsen A, Eskildsen P \& Pedersen BK. Elevated plasma interleukin-18 is a marker of insulin-resistance in type 2 diabetic and non-diabetic humans. Clinical Immunology 2005 117 152-160. (https://doi.org/10.1016/j.clim.2005.07.008)

35 Brahimaj A, Ligthart S, Ghanbari M, Ikram MA, Hofman A, Franco OH, Kavousi M \& Dehghan A. Novel inflammatory markers for incident pre-diabetes and type 2 diabetes: the Rotterdam Study. European Journal of Epidemiology 201732 217-226. (https://doi. org/10.1007/s10654-017-0236-0)

36 Hivert MF, Sun Q, Shrader P, Mantzoros CS, Meigs JB \& Hu FB. Circulating IL-18 and the risk of type 2 diabetes in women. Diabetologia 200952 2101-2108. (https://doi.org/10.1007/s00125009-1455-z)

37 Thorand B, Kolb H, Baumert J, Koenig W, Chambless L \& Meisinger C. Elevated levels of interleukin-18 predict the development of type 2 diabetes: results from the MONICA/KORA Augsburg Study, 1984-2002. Diabetes 200554 2932-2938. (https://doi.org/10.2337/diabetes.54.10.2932)

38 Trøseid M, Seljeflot I, Hjerkinn EM \& Arnesen H. Interleukin-18 is a strong predictor of cardiovascular events in elderly men with the metabolic syndrome: synergistic effect of inflammation and hyperglycemia. Diabetes Care 200932 486-492. (https://doi. org/10.2337/dc08-1710)

39 Brooks-Worrell BM \& Palmer JP. Latent Autoimmune Diabetes in Adults: Immunoendocrinology: Scientific and Clinical Aspects (Contemporary Endocrinology), pp 315-330. New York, NY, USA: Humana Press, 2011.

40 World Medical Association. World Medical Association Declaration of Helsinki: ethical principles for medical research involving human subjects. JAMA $2013 \mathbf{3 1 0} 2191-2194$.

41 Turner R, Stratton I, Horton V, Manley S, Zimmet P, Mackay IR, Shattock M, Bottazzo GF \& Holman R. UKPDS 25: autoantibodies to islet-cell cytoplasm and glutamic acid decarboxylase for prediction of insulin requirement in type 2 diabetes. UK Prospective Diabetes Study Group. Lancet 1997350 1288-1293. (https://doi.org/10.1016/ S0140-6736(97)03062-6)

42 Tiberti C, Giordano C, Locatelli M, Bosi E, Bottazzo GF, Buzzetti R, Cucinotta D, Galluzzo A, Falorni A \& Dotta F. Identification of tyrosine phosphatase 2(256-760) construct as a new, sensitive marker for the detection of islet autoimmunity in type 2 diabetic patients: the non-insulin requiring autoimmune diabetes (NIRAD) study 2. Diabetes 200857 1276-1283. (https://doi.org/10.2337/db07-0874)

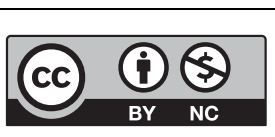

This work is licensed under a Creative Commons Attribution-NonCommercial 4.0 International License. 
43 Lampasona V, Petrone A, Tiberti C, Capizzi M, Spoletini M, di Pietro S, Songini M, Bonicchio S, Giorgino F, Bonifacio E, et al. Zinc transporter 8 antibodies complement GAD and IA-2 antibodies in the identification and characterization of adult-onset autoimmune diabetes. Diabetes Care 201033 104-108. (https://doi.org/10.2337/ dc08-2305)

44 International Diabetes Federation. The IDF Consensus Worldwide Definition of the Metabolic Syndrome. Brussels, Belgium: IDF, 2006. (available at: https://www.idf.org/e-library/consensus-statements/60idfconsensus-worldwide-definitionof-the-metabolic-syndrome)

45 Pham MN, Hawa MI, Pfleger C, Roden M, Schernthaner G, Pozzilli P, Buzzetti R, Scherbaum WA, Seissler J, Kolb H, et al. Pro- and antiinflammatory cytokines in latent autoimmune diabetes in adults, type 1 and type 2 diabetes patients: action LADA 4. Diabetologia 2011 54 1630-1638. (https://doi.org/10.1007/s00125-011-2088-6)

46 Tanti JF, Ceppo F, Jager J \& Berthou F. Implication of inflammatory signaling pathways in obesity-induced insulin resistance. Frontiers in Endocrinology 20133 181. (https://doi.org/10.3389/fendo.2012.00181)

47 Bosch M, Lopez-Bermejo A, Vendrell J, Musri M, Ricart W \& Fernandez-Real JM. Circulating IL-18 concentration is associated with insulin sensitivity and glucose tolerance through increased fatfree mass. Diabetologia 200548 1841-1843. (https://doi.org/10.1007/ s00125-005-1859-3)

48 Ballak DB, Stienstra R, Tack CJ, Dinarello CA \& van Diepen JA. IL-1 family members in the pathogenesis and treatment of metabolic disease: focus on adipose tissue inflammation and insulin resistance. Cytokine 201575 280-290. (https://doi.org/10.1016/j. cyto.2015.05.005)

49 Chiu HK, Tsai EC, Juneja R, Stoever J, Brooks-Worrell B, Goel A $\&$ Palmer JP. Equivalent insulin resistance in latent autoimmune diabetes in adults (LADA) and type 2 diabetic patients. Diabetes Research and Clinical Practice 200777 237-244. (https://doi. org/10.1016/j.diabres.2006.12.013)

50 Lohmann T, Kellner K, Verlohren HJ, Krug J, Steindorf J, Scherbaum WA \& Seissler J. Titre and combination of ICA and autoantibodies to glutamic acid decarboxylase discriminate two clinically distinct types of latent autoimmune diabetes in adults (LADA). Diabetologia 200144 1005-1010. (https://doi.org/10.1007/ s001250100602)

51 Katakami N, Kaneto H, Matsuhisa M, Yoshiuchi K, Kato K, Yamamoto K, Umayahara Y, Kosugi K, Hori M \& Yamasaki Y. Serum interleukin-18 levels are increased and closely associated with various soluble adhesion molecule levels in type 1 diabetic patients. Diabetes Care 200730 159-161. (https://doi.org/10.2337/dc06-1768)

52 Boraschi D \& Dinarello CA. IL-18 in autoimmunity: review. European Cytokine Network 200617 224-252. (https://doi.org/10.1684/ ecn.2006.0047)

53 Harms RZ, Yarde DN, Guinn Z, Lorenzo-Arteaga KM, Corley KP, Cabrera MS \& Sarvetnick NE. Increased expression of IL-18 in the serum and islets of type 1 diabetics. Molecular Immunology 201564 306-312. (https://doi.org/10.1016/j.molimm.2014.12.012)

54 Zaharieva ET, Velikova TV, Tsakova AD \& Kamenov ZA. Prevalence of positive diabetes-associated autoantibodies among type 2 diabetes and related metabolic and inflammatory differences in a sample of the Bulgarian population. Journal of Diabetes Research 20172017 9016148. (https://doi.org/10.1155/2017/9016148)

55 Altinova AE, Yetkin I, Akbay E, Bukan N \& Arslan M. Serum IL-18 levels in patients with type 1 diabetes: relations to metabolic control and microvascular complications. Cytokine 200842 217-221. (https://doi.org/10.1016/j.cyto.2008.02.006)

56 Böni-Schnetzler M, Ehses JA, Faulenbach M \& Donath MY. Insulitis in type 2 diabetes. Diabetes, Obesity and Metabolism 200810 201-204. (https://doi.org/10.1111/j.1463-1326.2008.00950.x)

57 Maedler K, Sergeev P, Ris F, Oberholzer J, Joller-Jemelka HI, Spinas GA, Kaiser N, Halban PA \& Donath MY. Glucose-induced $\beta$ cell production of IL-1 $\beta$ contributes to glucotoxicity in human pancreatic islets. Journal of Clinical Investigation $2002110851-860$. (https://doi.org/10.1172/JCI15318)

58 Hawa MI, Kolb H, Schloot N, Beyan H, Paschou SA, Buzzetti R, Mauricio D, De Leiva A, Yderstraede K, Beck-Neilsen H, et al. Adultonset autoimmune diabetes in Europe is prevalent with a broad clinical phenotype: action LADA 7. Diabetes Care 201336 908-913. (https://doi.org/10.2337/dc12-0931)

59 Lohmann T, Kellner K, Verlohren HJ, Krug J, Steindorf J, Scherbaum WA \& Seissler J. Titre and combination of ICA and autoantibodies to glutamic acid decarboxylase discriminate two clinically distinct types of latent autoimmune diabetes in adults (LADA). Diabetologia 200144 1005-1010. (https://doi.org/10.1007/ s001250100602)

60 Rolandsson $\mathrm{O} \&$ Palmer JP. Latent autoimmune diabetes in adults (LADA) is dead: long live autoimmune diabetes! Diabetologia 201053 1250-1253.

Received in final form 30 November 2017

Accepted 7 December 2017

Accepted Preprint published online 7 December 2017 http://www.endocrineconnections.org https://doi.org/10.1530/EC-17-0273
() 2018 The authors Published by Bioscientifica Ltd

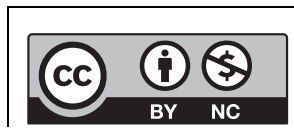

This work is licensed under a Creative Commons Attribution-NonCommercial 4.0 International License. 